\title{
PENGELOLAAN BADAN USAHA MILIK DESA DALAM MENINGKATKAN KESEAHTERAAN MASYARAKAT PERDESAAN KAWASAN PERTAMBANGAN EMAS DI KABUPATEN SUMBAWA BARAT
}

\author{
Management Of Village Business Enterprises In Improving \\ Community Welfare Resilience Of Gold Mining Areas In Sumbawa \\ Barat District
}

Ibrahim $^{1}$, Iwan Tanjung Sutarna ${ }^{2}$

Diterima: 22 Desember 2017

Disetujui: 19 Februari 2018

\begin{abstract}
Abstrak: Potensi Kabupaten Sumbawa Barat pada perdesaan kawasan pertambangan emas sangat melimpah, namun memiliki tingkat kemiskinan masih tingggi. Keberadaan Badan Usaha Milik Desa (BUMDes) sebagai alternatif dalam mengembangkan potensi yang dimiliki dalam meningkatkan pendapatan desa dan masyarakat. Penelitian ini bertujuan mengkaji kelebihan dan kelemahan pengelolaan BUMDes dalam meningkatkan kesejahteraan masyarakat pada perdesaan kawasan pertambangan emas di Kabupaten Sumbawa Barat. Penelitian ini menggunakan pendekatan kualitatif deskriptif. Pengambilan data dilakukan pada perdesaan kawasan pertambangan emas Kabupaten Sumbawa Barat. Kecamatan yang termasuk dalam kawasan pertambangan emas yaitu: Kecamatan Jereweh, Maluk dan Sekongkang. Teknik pengumpulan data menggunakan wawancara, dokumentasi, dan observasi dengan subyek penelitian dari pihak desa, pengelola BUMDES, masyarakat penerima manfaat program dan instansi terkait. Validitas data menggunakan teknik triangulasi. Analisis data menggunakan reduksi, display, verifikasi dan kesimpulan. Hasil penelitian ini menunjukkan bahwa BUMDES pada perdesaan kawasan pertambangan emas belum berhasil secara total dalam peningkatan kesejahteraan masyarakat dari unit-unit program BUMDES yang ada. BUMDES Kawasan pertambangan emas memiliki kelebihan yaitu: a) mudahnya akses keuangan dan b) peningkatan ekonomi rumah tangga. Kelemahan : a) Sumberdaya Manusia pengelola dan b) rencana usaha rendah. Perlu adanya partitipasi aktif dari masyarakat dalam menjalan program BUMDes menuju ekonomi berkemajuan.
\end{abstract}

\section{Kata kunci : Kelebihan, Kelemahan, BUMDes, Kesejahteraan Masyarakat}

Abstract: The potential of West Sumbawa Regency in rural gold mining area is very abundant, but has a high level of poverty. The existence of Village Owned Enterprises (BUMDes) as an alternative in developing the potential owned in increasing the income of villages and communities. This study aims to examine the advantages and disadvantages of the management of BUMDes in improving the welfare of society in rural gold mining area in West Sumbawa regency. This research uses descriptive qualitative approach. Data collection is done in rural gold mining area of West Sumbawa Regency. Subdistricts included in the gold mining areas are: District Jereweh, Maluk and

\footnotetext{
${ }^{1}$ Program Studi Pendidikan Geografi Universitas Muhammadiyah Mataram

${ }^{2}$ Program Studi Ilmu Pemerintahan Universitas Muhammadiyah Mataram
}

Korespondensi: ibrahimali.geo@gmail.com 
Sekongkang. Data collection techniques used interviews, documentation, and observation with research subjects from the village, BUMDES management, beneficiary communities and related institutions. Data validity using triangulation technique. Data analysis using reduction, display, verification and conclusion. The results of this study indicate that BUMDES in rural gold mining areas has not been successful in total in improving the welfare of the community from the existing BUMDES program units. BUMDES Gold mining areas have advantages that are: a) easy access to finance and b) improvement of household economy. Weaknesses: a) Human resources managers and $b$ ) business plans are low. There needs to be active partitipasi from society in running BUMDes program to economy progress.

Keywords: Advantages, Weaknesses, BUMDes, Public Welfare

\section{PENDAHULUAN}

Pembangunan merupakan proses perubahan dari proses perencanaan dengan tujuan untuk meningkatkan kesejahteraan masyarakat. Undang-Undang No. 6 Tahun 2014 tentang Desa dalam Pasal 78 menyatakan bahwa: 1) Pembangunan Desa bertujuan meningkatkan kesejahteraan masyarakat desa dan kualitas hidup manusia serta penanggulangan kemiskinan melalui pemenuhan kebutuhan dasar, pembangunan sarana dan prasarana desa, pengembangan potensi ekonomi lokal, serta pemanfaatan sumber daya alam dan lingkungan secara berkelanjutan. 2) Pembangunan desa meliputi tahap perencanaan, pelaksanaan, dan pengawasan. 3) Pembangunan desa sebagaimana dimaksud pada ayat (2) mengedepankan kebersamaan, kekeluargaan, dan kegotongroyongan guna mewujudkan pengarusutamaan perdamaian dan keadilan sosial.

Pembangunan desa lebih dekat dengan masyarakat. Desa sebagai wakil pemerintah paling depan dalam pembangunan. Makanya kewenangan desa untuk mengelola wilayahnya secara mandiri dan berkelanjutan. peranan pemerintah desa dalam pelaksanaan pembangunan dari perencanaan, pelaksanaan dan evaluasinya berdasarkan undang-undang yang berlaku. pemerintah desa diberikan dukungan besar agar desa memiliki badan usaha yang mampu mengembangkan dan menggerakkan perekonomian lokal.

Berlakunya Undang-Undang No. 32 tahun 2004 tentang Pemerintah Daerah, telah mendorong desa mengembangkan Badan Usaha Milik Desa (BUMDes) sesuai dengan kebutuhan dan potensi yang dimiliki masing-masing desa dalam meningkatkan pendapatan masyarakat dan pendapatan asli desa. BUMDes menjadi wadah bagi pemerintah desa dan wmasyarakat yang secara proporsional melaksanakan program pemberdayaan perekonomian di tingkat desa.

Keberadaan BUMDes sebagai lembaga ekonomi desa menjadi salah satu program desa sebagai sarana untuk meningkatkan Pendapatan Asli Desa (PADes). Peranan BUMDes sebagai instrumen penguatan otonomi desa dan juga sebagai instrumen kesejahteraan masyarakat. Pemerintah desa memiliki kekuasaan dalam mengembangkan potensi sesuai dengan kemampuan desa. Keterlibatan masyarakat dalam pengelolaan BUMDes akan dapat mendorong dibukanya usaha baru dan dapat mengurangi tingkat mengangguran.

Kabupaten Sumbawa Barat sebagai kabupaten terpenting di Provinsi Nusa Tenggara Barat. Kabupaten sebagai penghasil Sumberdaya Alam yang melimpah dan mampu memberikan memanfaatkan potensi ini guna kepentingan pelaksanaan pembangunan daerah khususnya di bidang pembangunan dan penyediaan infrastruktur dasar. Selain potensi tersebut Kabupaten Sumbawa Barat memiliki potensi yang belum dikelola secara maksimal untuk meningkatkan kesejahteraan masyarakat meliputi: pertanian (pertanian tanaman pangan, perikanan dan kelautan, kehutanan, perkebunan, peternakan), pariwisata, industri, perdagangan, perhubungan. 
Potensi yang dimiliki Kabupaten Sumbawa Barat terutama pada perdesaan kawasan pertambangan emas sangat melimpah, namun memiliki tingkat kemiskinan masih tingggi (Tabel 1). Jumlah keluarga sejahtera pada perdesaan kawasan pertambangan emas terutama kecamatan Sekongkang sebanyak $2.022 \mathrm{KK}$, Jereweh sebanyak $2.290 \mathrm{KK}$ dan Maluk sebanyak $2.052 \mathrm{KK}$ ) masih tinggi dibandingkan desa yang tidak memiliki Sumberdaya Alam yaitu Kecamatan Brang Rea sebanyak $1.667 \mathrm{KK}$ ). Artinya diperlukan adanya model dan strategi dalam penanggulangan kemiskinan pada kawasan pertambangan.

Tabel 1. Banyaknya Keluarga Menurut Kecamatan dan Klasifikasi Keluarga di Kabupaten Sumbawa Barat Tahun 2014

\begin{tabular}{|c|c|c|c|c|c|c|}
\hline \multirow[t]{2}{*}{ Kecamatan } & \multirow{2}{*}{$\begin{array}{l}\text { Pra } \\
\text { Sejahtera }\end{array}$} & \multicolumn{4}{|c|}{ Keluarga Sejahtera } & \multirow[t]{2}{*}{ Jumlah } \\
\hline & & I & II & III & III+ & \\
\hline 1. Sekongkang & 238 & 524 & 673 & 587 & - & 2.022 \\
\hline 2. Jereweh & 281 & 543 & 916 & 550 & - & 2.290 \\
\hline 3. Maluk & 118 & 338 & 638 & 958 & - & 2.052 \\
\hline 4. Taliwang & 1.252 & 1.722 & 4.763 & 4.416 & 5 & 12.158 \\
\hline 5. Brang Ene & 96 & 181 & 1.080 & 289 & 21 & 1.667 \\
\hline 6. Brang Rea & 285 & 377 & 521 & 2.631 & - & 3.814 \\
\hline 7. Seteluk & 813 & 1.760 & 2.192 & 219 & 1 & 4.985 \\
\hline 8. Poto Tano & 853 & 1.114 & 663 & 42 & - & 2.672 \\
\hline Jumlah & 3.936 & 6.559 & 11.446 & 9.692 & 27 & 31.660 \\
\hline
\end{tabular}

Sumber: Badan Pusat Stataistik Sumbawa Barat, 2017

Keberadaan BUMDes sebagai alternatif dalam mengembangkan potensi yang dimiliki dalam meningkatkan pendapatan desa dan masyarakat. Program BUMDes menunjukan konstribusi penting dalam peningkatan akses terhadap pelayanan jasa keuangan pada tingkat perdesaan sebagai proses pumutusan mata rantai kemiskinan serta pada akhirnya dapat meningkatkan pertumbuhan ekonomi desa dan kesejahteraan individu.

Berdasarkan paparan diatas, penelitian ini bertujuan mengkaji kelebihan dan kelemahan pengelolaan BUMDes dalam meningkatkan kesejahteraan masyarakat pada perdesaan kawasan pertambangan emas di Kabupaten Sumbawa Barat

\section{METODE}

Pengambilan data dalam penelitian dilakukan pada perdesaan kawasan pertambangan emas Kabupaten Sumbawa Barat. Lokasi penelitian ini mewakili 3 (tiga) kecamatan yang termasuk dalam kawasan pertambangan emas terdiri dari : Kecamatan Jereweh, Maluk dan Sekongkang.

Data diperoleh dari tiga sumber yaitu: pertama, akan digali dari pengamatan langsung dari proses aktivitas pengelola BUMDes; kedua, diperoleh melalui informan (narasumber) yang terlibat langsung dilapangan pada program BUMDes; ketiga, informasi stakeholders pada pihak desa masing-masing yang memahami kondisi masyarakat dan pelaksanaan program BUMDes serta instansi terkait.

Pengumpulan data yang dilakukan dalam penelitian ini dengan menggunakan 4 (empat) cara antara lain: observasi, wawancara, perekaman dan pencatatan. Validitas data menggunakan teknik triangulasi sumber. Analisis data menggunakan model analisis interaktif yaitu analisis dengan menggunakan reduksi data, display data dan kesimpulan. 


\section{HASIL DAN PEMBAHASAN}

\section{Kelebihan dan Kelemahan Bumdes dalam Meningkatkan Kesejahteraan Masyarakat Perdesaan}

Dalam meningkatkan kesejahteraan masyarakat memiliki banyak ukuran dalam penilaian. Undang-Undang Nomor 11 Tahun 2009 Tentang Kesejahteraan Sosial pasal 1 ayat 1 , kesejahteraan sosial adalah kondisi terpenuhinya kebutuhan material, spiritual, dan sosial warga negara agar bisa hidup layak dan mampu mengembangkan diri sehingga dapat melaksanakan fungsi sosialnya. Upaya untuk mewujudkan suatu kesejahteraan sosial, meliputi rehabilitasi sosial, perlindungan sosial, pemberdayaan sosial, dan jaminan sosial

Keberadaan BUMDes dalam pemberdayaan sosial masyarakat sebagai alternatif kebijakan pemerintah dalam meningkatkan kesejahteraan. Program BUMDes dalam menjalankan program memberikan ruang untuk dapat keluar dari kemiskinan. Oleh karena itu, evaluasi sebagai dasar untuk mengetahui tingkat keberhasilan program yang sudah laksanakan.

Menurut Mulyatiningsih (2011) menjelaskan bahwa evaluasi program dilakukan dengan tujuan untuk: a) menunjukkan sumbangan program terhadap pencapaian tujuan organisasi. Hasil evaluasi ini penting untuk mengembangkan program yang sama ditempat lain dan b) mengambil keputusan tentang keberlanjutan sebuah program, apakah program perlu diteruskan, diperbaiki atau dihentikan.

Peran lembaga dalam mendukung program guna mencapai tujuan yang diharapkan. Menurut Mubyarto (1989), yang dimaksud lembaga adalah organisasi atau kaedah-kaedah baik formal maupun informal yang mengatur perilaku dan tindakan anggota masyarakat tertentu baik dalam kegiatan-kegiatan rutin sehari-hari maupun dalam usahanya untuk mencapai tujuan tertentu.

Peran kelembagaan sangat penting dalam mengatur sumberdaya dan distribusi manfaat, untuk itu unsur kelembagaan perlu diperhatikan dalam upaya peningkatan potensi desa guna menunjang pembangunan desa. Dengan adanya kelembagaan petani dan ekonomi desa sangat terbantu dalam hal mengatur silang hubungan antar pemilik input dalam menghasilkan output ekonomi desa dan dalam mengatur distribusi dari output tersebut.

BUMDes sebagai lembaga ekonomi baru dalam meningkatkan ekonomi perdesaan. Hal ini diperkuat berdasarkan Undang-Undang No 6 tahun 2014 tentang Desa memberikan payung hukum atas BUMDes sebagai pelaku ekonomi yang mengelola potensi desa secara kolektif untuk meningkatkan kesejahteraan warga desa. Lebih rinci keberadaan BUMDes dalam Peraturan Pemerintah No 72 tahun 2005 tentang Desa dan dirincikan melalui Peraturan Menteri Dalam Negeri No 39 Tahun 2010 tentang Badan Usaha Milik Desa. BUMDes merupakan wadah usaha desa yang memiliki semangat kemandirian, kebersamaan, dan kegotong-royongan antara pemerintah desa dan masyarakat untuk mengembangkan aset-aset lokal untuk memberikan pelayanan dan meningkatkan pendapatan ekonomi masyarakat dan desa.

Kelembagaan BUMDes dalam mendukung program pemberdayaan masyarakat perdesaan sangat diperlukan. Pelaksanaan program BUMDes menitikberatkan pada kawasan pertambangan emas Kabupaten Sumbawa Barat memiliki kelebihan dan kelemahan dalam meningkatkan pemberdayaan ekonomi masyarakat.

\section{Kelebihan Program}

a. Mudahnya Akses Keuangan

Potensi desa secara keseluruhan sangat kaya dengan dengan potensi Sumberdaya Alam dan memiliki tingkat ekonomi rendah. Pengelolaan sumberdaya yang dimiliki desa secara komprehensif dapat memberikan nilai tambah dalam meningkatkan ekonomi desa 
dan masyarakat. Adanya keterbatasan ekonomi masyarakat sebagai salah satu kendala utama dalam pengembangan ekonomi desa terutama lembaga keuangan dalam mendukung perekonomian desa.

Keberadaan BUMDes pada masyarakat perdesaan kawasan pertambangan emas di Kabupaten Sumbawa Barat sebagai terobosan dalam merangsang ekonomi masyarakat. Berdasarkan wawancara mendalam dengan MSL (penerima dampak Program) pada tanggal 16 Agustus 2017 menyebutkan bahwa keberadaan program BUMDes bagi kami masyarakat petani memiliki manfaat yang banyak terutama dalam usaha meningkatkan hasil pertanian. Keberadaan program simpan pinjam bisa kami gunakan mulai dari pembibitan, pembelian pupuk tanah, pupuk daun dan pasca panen. Kami terbantu adanya dana simpan pinjam tersebut dan pengembaliannya lebih banyak dilakukan pasca panen berlangsung.

Hal senada dari wawancara mendalam dengan RB (penerima dampak Program) pada tanggal 16 Agustus 2017 menyebutkan bahwa dengan adanya BUMDes dengan program simpan pinjam kami dimudahkan dalam meminjam, daripada kami meminjam ke Bank dan harus pergi jauh ke kabupaten tentu memelukan biaya tambahan lagi dalam perjalanan dan lainnya. Oleh karena adanya program simpan pinjam ini manfaat banyak kami untuk mengembangkan usaha kios yang kami miliki.

Berdasarkan hasil wawancara diatas dapat disimpulkan bahwa keberadaan program BUMDes memberikan kemudahan akses keuangan bagi masyarakat dalam mendukung usaha ekonomi. Menurut Tampubolon (2017) Bentuk Badan Usaha Milik Desa (BUMDes) merupakan pilihan model lembaganya. Pertimbangan utama dalam sistem pembiayaan adalah sanksi, beban bunga bagi pembiayaan, agunan dan biaya administrasi.

Pernyataan ini diperkuat Wicaksono dkk (2017) menjelaskan bahwa Peran Badan Usaha Milik Desa (BUMDes) Amanah Dalam Meningkatkan Pendapatan Asli Desa adalah melalui pengelolaan keuangan yang baik dengan alur akuntansi, melalui pengelolaan aset desa yang menjadi sumber usaha seperti unit air bersih, unit kebun desa dan unit pasar desa, pengelola BUMDes Amanah sudah mampu mengadakan kerjasama dengan pihak ketiga yaitu sebagai agen BRILink. BUMDes sudah berperan dalam meningkatkan pendapatan asli desa melalui tiga unit usaha utama yaitu unit air bersih, unit kebun desa, unit pasar desa yang didalamnya terdapat penyewaan tenda, ditambah unit pembantu yaitu saprodi dan kerjasama dengan perbankan menjadi agen BRILink

\section{b. Peningkatan Ekonomi Rumah Tangga}

BUMDes merupakan lembaga moneter desa (unit pembiayaan) sebagai unit yang yang melakukan transaksi keuangan berupa kredit maupun simpan pinjam. Keberadaan BUMDes sebagai alternatif untuk menopang ekonomi masyarakat desa. Keberhasilan ekonomi masyarakat perdesaan di indikator dengan tingginya pertumbuhan ekonomi dan disertai dengan pemerataan distribusi aset secara luas.

Pemerataan dan pertumbuhan ekonomi masyarakat melalui keberadaan BUMDes memberikan dampak terhadap peningkatan ekonomi rumah tangga di masyarakat perdesaan. Berdasarkan wawancara mendalam dengan ATK (penerima dampak Program) pada tanggal 17 Agustus 2017 menyebutkan bahwa keberadaan program simpan pinjam dari BUMDes memberikan penambahan modal usaha, sehingga mampu memberikan pengembangan usaha kios yang lebih maju. Usaha sebelumnya belum mampu memberikan tambahan modal karena terbatas jumlah barang yang jual. Oleh karena itu, dampak dana simpan pinjam ini bisa meningkatkan usaha dan meningkatkan pendapatan rumah tangga.

Berdasarkan data diatas dapat disimpulkan bahwa program simpan pinjam mampu memberikan peluang dalam meningkatkan pendapatan ekonomi rumah tangga. Pernyataan ini diperkuat Puspasari dan Sariffuddin (2015) menjelaskan bahwa terdapat pola peningkatan kesejahteraan secara informal melalui perubahan mata pencaharian yang pada akhirnya meningkatkan pendapatan warga. Hal ini diperkuat hasil penelitian Hayyuna dkk (2017) 
menjelaskan bahwa strategi manajemen yang telah dilakukan oleh BUMDES dapat meningkatkan pendapatan Desa dari tahun 2010 sampai dengan tahun 2012.

\section{Kelemahan Program BUMDes}

a. Sumberdaya Manusia Pengelola

Keberadaan BUMDes ditengah masyarakat dapat memberikan pergerakan ekonomi dan membantu meningkatkan peluang usaha ekonomi masyarakat secara mandiri. Menurut Sayutri (2011) mengemukakan bahwa keberadaan BUMDes diperlukan guna menggerakkan potensi desa serta dapat membantu dalam upaya pengentasan kemiskinan.

BUMDes pada perdesaan kawasan pertambangan emas di Kabupaten Sumbawa Barat tidak hanya memiliki keunggalan tetapi masih memiliki kelemahan. Berdasarkan wawancara mendalam dengan NNG (Staff Desa) pada tanggal 11 Agustus 2017 menyatakan bahwa program simpan pinjam yang di kembangkan BUMDes sampai saat ini belum berkembang karena minimnya Sumberdaya Manusia dan banyaknya pengurus BUMDes rangkap jabatan ditempat lain, sehingga program BUMDes hanya sebagai program sampingan atau sambilan.

Berdasarkan hasil wawancara tersebut diatas bahwa faktor keterbatasan Sumberdaya Manusia yang mengelola BUMDes juga menjadi kelemahan dalam mengembangkan BUMDes. Selain itu rangkap jabatan pada pada lembaga lain, sehingga pengembangan BUMDes untuk masa akan datang menjadi sulit dan kurang fokusnya pengelola.

Pernyataan ini diperkuat dari hasil penelitian Agunggunanto dkk, (2016) menunjukkan bahwa kondisi BUMDes di Kabupaten Jepara sudah berjalan sesuai dengan tujuan pembentukan BUMDes dan mampu membantu meningkatkan perekonomian desa. Namun, masih terdapat kendala dalam pengelolaan BUMDes di beberapa daerah seperti jenis usaha yang dijalankan masih terbatas, keterbatasan sumber daya manusia yang mengelola BUMDes dan partisipasi masyarakat yang rendah karena masih rendahnya pengetahuan mereka. Senada dengan hal Pernyataan diatas Purnamasari dkk (2016) menjelaskan baahwa masyarakat desa kekurangan sumber daya manusia yang mampu menjalankan manajemen dan pengelolaan keuangan, masyarakat desa juga kurang memperoleh informasi tentang pembentukan BUM Desa. Dengan demikian dalam pencapaian tujuan efektifitas pengelolaan BUM Desa masih belum efektif dan efisien

\section{a. Rencana Usaha rendah}

Rencana usaha yang sesuai dengan potensi dan kebutuhan salah satu ukuran keberhasilan dalam pengembangan usaha. Kemampuan merencanakan usaha dalam sebuah bisnis akan dapat menghasilkan keuntungan dan menarik penyandang dana. Perencanaan usaha juga harus didasarkan pada kebutuhan masyarakat akan adanya sumber pendanaan, barang dan jasa yang ditawarkan, sehingga perencanaan usaha harus berbasis pada permintaan pasar.

Keberadaan BUMDes sebagai penguat ekonomi dalam mengembang usaha yang diperlukan masyarakat. Menyusun rencana usaha dalam pengelolaan BUMDes sangat diperlukan. Perencanaan yang matang dalam rencana usaha menghindari terjadinya hal yang tidak diinginkan. Karena dari beberapa pengalaman yang membuka usaha tidak sedikit usahanya gagal walaupun telah melakukan perencanaan yang baik. Pengelolaan usaha BUMDes perlu adanya perencanaan yang baik dan mampu memberikan dampak keberadaan dalam meningkatkan ekonomi masyarakat. Pengelola BUMDes harus mematuhi rambu atau kaidah-kaidah bisnis yang bertujuan mengantisipasi risiko yang muncul dikemudian hari. 
Usaha BUMDes terutama pada perdesaan kawasan pertambangan emas Kabupaten Sumbawa Barat persebarannya beragam (Tabel 2). Namun memiliki perencanaan usaha masih secara tradisional. Berdasarkan wawancara mendalam dengan NNG (Staff Desa) pada tanggal 11 Agustus 2017 menyatakan bahwa keberadaan BUMDes pada desa kami masih fokus pada usaha simpan pinjam dan belum bisa memikirkan untuk pengembangan kedepan. Karena masih memiliki kendala terutama pengurus sering ganti dan pengembalian dana simpan pinjam tidak berjalan.

Tabel 2. Persebaran Program Bumdes di Kawasan Pertambangan Emas Kabupaten Sumbawa Barat

\begin{tabular}{|c|c|c|c|c|}
\hline No & Kecamatan & Desa & Nama Bumdes & Program \\
\hline \multirow[t]{2}{*}{1} & Jereweh & Beru & Saling Pendi & Simpan Pinjam \\
\hline & & $\begin{array}{l}\text { Dasan } \\
\text { Anyar }\end{array}$ & Bumdes Dasan Anyar & Simpan Pinjam \\
\hline \multirow[t]{2}{*}{2} & Maluk & $\begin{array}{l}\text { Bukit Damai } \\
\text { Mantun }\end{array}$ & $\begin{array}{l}\text { Bumdes Makmur Bersama } \\
\text { Bumdes Saling Pariri }\end{array}$ & $\begin{array}{l}\text { Retribusi Sampah, Lapak Desa, Kos-Kosan } \\
\text { Retribusi Stand Dan Pedagang Kaki Lima } \\
\text { Di Terminal }\end{array}$ \\
\hline & & Maluk & Bumdes Mampis Rungan & $\begin{array}{l}\text { Unit Pasar, Parkir, Unit Sampah, } \\
\text { Pengelolaan Bangunan, Aset Desa }\end{array}$ \\
\hline 3 & Sekongkang & - & - & - \\
\hline
\end{tabular}

Sumber : BPMPD Kabupaten Sumbawa Barat, 2017

Pernyataan diatas diperkuat dari hasil wawancara menadalam dengan RR (Kabag Pemberdayaan Desa) pada Tanggal 16 Agustus 2017 menyebutkan bahwa kendala yang dihadapi pada pihak desa dalam pembentukan dan menjalankan program BUMDes meliputi: lemahnya Sumberdaya Manusia, Bisnis Planning lemah, dan potensi ekonomi belum tertata.

Berdasarkan data diatas dapat disimpulkan bahwa keberadaan BUMDes pada perdesaan kawasan pertambangan emas dalam mendukung pemberdayaan ekonomi masyarakat belum maksimal. Pernyataan ini diperkuat Anggraeni (2016) menjelaskan bahwa keberadaan BUMDes tidak dipungkiri membawa perubahan di bidang ekonomi dan sosial. Keberadaan BUMDes tidak membawa manfaat signifikan bagi peningkatan kesejahteraan warga secara langsung, Permasalahan yang muncul terkait BUMDes adalah akses masyarakat terhadap air dan akses masyarakat untuk mendapatkan pekerjaan di BUMDes.

Hal dipekuat dari hasil penelitian Goma (2017) peran pemerintah desa dalam meningkatkan pendapatan desa belum sepenuhnya berhasil, hal ini dapat dibuktikan dengan belum adanya kebijakan dari pemerintah desa secara konkrit yaitu peraturan desa yang memuat tentang pembentukan badan usaha milik desa serta pengelolaannya yang masih belum transparan dan akuntabel sehingga belum memberikan kontribusi yang berarti bagi peningkatan pendapatan di desa.

\section{KESIMPULAN}

Berdasarkan hasil temuan dari penelitian ini dapat dikatakan bahwa kelebihan dan kelemahan pengelolaan Badan Usaha Milik Desa dalam meningkatkan kesejahteraan masyarakat perdesaan kawasan pertambangan emas di Kabupaten Sumbawa Barat menunjukkan bahwa belum berhasil secara total dalam peningkatan perekonomian desa dan kesejahteraan masyarakat dari unit-unit BUMDES yang ada. Pengelolaan BUMDES Kawasan pertambangan emas memiliki kelebihan yaitu: a) mudahnya akses keuangan dan b) peningkatan ekonomi rumah tangga. Kelemahan : a) Sumberdaya Manusia pengelola dan b) rencana usaha rendah. 


\section{DAFTAR PUSTAKA}

Agunggunanto, Yusuf Edy, Arianti Fitrie, Kushartono Wibowo Edi dan Darwanto, 2016, Pengembangan Desa Mandiri Melalui Pengelolaan Badan Usaha Milik Desa (Bumdes), Jurnal Ekonomi dan Bisnis, Vol. 13. No.1 Maret 2016, Hal: 67-81

Anggraeni, Maria Rosa Ratna Sri, 2016, Peranan Badan Usaha Milik Desa (BUMDes) Pada Kesejahteraan Masyarakat Pedesaan Studi Pada Bumdes Di Gunung Kidul, Yogyakarta, Modus, Vol. 28 (2), Hal: 155167

Goma, Subhan, 2017, Peran Pemerintah Desa Dalam Meningkatkan Pendapatan Di Desa Bolangitang Satu Kecamatan Bolang Itang Kabupaten Bolaang Mongondow Utara, diakses https://media.neliti.com/media/publications/1114-ID-peran-pemerintah-desa-dalam-meningkatkanpendapatan-di-desa-bolangitang-satu-kec.pdf Pada tanggal 10 Agustus 2017

Hayyuna, Rizka, Pratiwi, Ratih Nur, Dan Mindati, Lely Indah, 2017, Strategi Manajemen Aset Bumdes Dalam Rangka Meningkatkan Pendapatan Desa (Studi Pada Bumdes Di Desa Sekapuk, Kecamatan Ujungpangkah, Kabupaten Gresik)

Mubyarto, 1989, Pengantar Ekonomi Pertanian, Lembaga Penelitian, Pendidikan dan Penerangan Ekonomi dan Sosial, Jakarta

Mulyatiningsih, Endang, 2011, Evaluasi Proses Suatu Program, Jakarta, Bumi Aksara

Peraturan Menteri Dalam Negeri No 39 Tahun 2010 tentang Badan Usaha Milik Desa

Peraturan Pemerintah No 72 tahun 2005 tentang Desa

Purnamasari, Hanny, Yuliana Eka, Ramdani Rachmat, 2016, Efektivitas Pengelolaan Badan Usaha Milik Desa (BUMDes) Berbasis Ekonomi Kerakyatan Di Desa Warungbambu Kecamatan Karawang Timur Kabupaten Karawang, Jurnal Politikom Indonesiana, Vol. 1 No. 2, Desember 2016, E-ISSN: 2528 - 2069, Hal: $31-42$

Puspasari,Deny Aditya Dan Sariffuddin, 2015, Peran Gender Dalam Peningkatan Kesejahteraan Masyarakat Desa Wisata Colo Kabupaten Kudus, Tata Loka, Vol. 17, No. 4 November 2015-P Issn 0852-7458-E Issn 23560266

Sayutri, M. 2011, Pelembagaan Badan Usaha Milik Desa (BUMDes) sebagai penggerak Potensi Ekonomi Desa dalam Upaya pengentasan Kemiskinan di Kabupaten Donggala, Jurnal Academica, Fisip Untad, 3(2), Hal: 717-728

Tampubolon, Dahlan, 2017, Lembaga Keuangan Mikro Pedesaan di Kabupaten Bengkalis, diakses https://media.neliti.com/media/publications/8755-ID-lembaga-keuangan-mikro-pedesaan-dikabupaten-bengkalis.pdf Pada Tanggal 20 Agustus 2017

Undang-Undang No. 32 tahun 2004 tentang Pemerintah Daerah

Undang-Undang No. 6 Tahun 2014 tentang Desa

Undang-Undang Nomor 11 Tahun 2009 Tentang Kesejahteraan Sosial

Wicaksono, Yoni Pramilu, Surya Iman, Dan Iskandar Eddy, 2017, Peran Badan Usaha Milik Desa (BUMDes) Amanah Dalam Meningkatkan Pendapatan Asli Desa Padang Jaya Kecamatan Kuaro Kabupaten Paser, Ejournal Ilmu Pemerintahan, 2017, Vol 5 (4): 1637-1650, ISSN 2477 -2458 (Online), ISSN 2477 - 2631 (Cetak) 